\title{
Kas İskelet Sistemi Yakınması Olmayan Osteoartiküler Bruselloz
}

\section{$\underline{\text { Ertugrul GUCLU }}^{1}, \underline{\text { Yusuf DURMAZ }}^{2}, \underline{\text { Oguz KARABAY }}^{1}$}

\begin{tabular}{|c|c|}
\hline \\
\hline \multicolumn{2}{|l|}{$\begin{array}{l}\ddot{\mathbf{O ̈ z}} \\
\text { Bruselloz gelişmekte olan ülkelerin önemli sağlı problemlerindendir. Hastaların }\end{array}$} \\
\hline \multirow{5}{*}{$\begin{array}{l}\ddot{O} z \\
\text { Bruselloz gelişmekte olan ülkelerin önemli sağlık problemlerindendir. Hastaların } \\
\text { ana şikayetleri halsizlik, iştahsılık, eklem ağrısı ve terlemedir. Kas iskelet sistemi } \\
\text { tutulumu en fazla görülen komplikasyonudur. Bu olgu sunumunda kas iskelet } \\
\text { sistemi tutulumu ile ilgili şikayetleri olmayan bir hastada tespit edilen bruselloza } \\
\text { bağlı spondilit ve spondilodiskit olgusuna dikkat çekmek amaçlanmıstır. Hastanın } \\
\text { tanısı rastlantısal olarak çekilen manyetik rezonans görüntüleme ile konulmuştur. }\end{array}$} & Kabul Tarihi: 13.04.2019 \\
\hline & Online Yayın Tarihi: 31.12.2019 \\
\hline & DOI: $10.26453 /$ otjhs. 527316 \\
\hline & \\
\hline & Sorumlu Yazar \\
\hline \multirow{3}{*}{ Anahtar Kelimeler: Bruselloz, spondilodiskit, semptom } & Ertugrul GUCLU \\
\hline & \\
\hline & $\begin{array}{r}\text { Department of Infectious Diseases and } \\
\text { Clinical Microbiology, } \\
\text { 54100, Sakarya, Turkey } \\
\text { Tel: } 02642759192 \\
\text { E Mail: ertugrulguclu@ @otmail.com }\end{array}$ \\
\hline
\end{tabular}

\section{Osteoarticular Brucellosis without Musculoskeletal Complaints}

$\underline{\text { Ertugrul GUCLU }}^{1}, \underline{\text { Yusuf DURMAZ }}^{2}, \underline{\text { Oguz KARABAY }}^{1}$

\begin{abstract}
Brucellosis is one of the major health problem in developing countries. Main complaints of patients are weakness, fatigue, joint pain, and sweating. Musculoskelatal system involvement is the most seen complication. In this case report, we aimed to draw attention to a brucellar spondylitis and spondylodiscitis case who does not have any complaints about the involvement of musculoskeletal system. His diagnosis was made with magnetic resonance imaging incidentally.
\end{abstract}

Keywords: Brucellosis, spondylodiscitis, symptom
Article Info

Received: 14.02 .2019

Accepted: 13.04 .2019

Online Published: 31.12.2019

DOI: $10.26453 /$ otjhs.527316

Corresponding Author Ertugrul GUCLU

Sakarya University

Faculty of Medicine

Department of Infectious Diseases and Clinical Microbiology,

54100, Sakarya, Turkey

Tel: 02642759192

E Mail: ertugrulguclu@ hotmail.com

${ }^{1}$ Department of Infectious Diseases and Clinical Microbiology, Sakarya University Faculty of Medicine, Sakarya, Turkey

${ }^{2}$ Division of Intensive care Unit, Dr Suat Seren Chest Diseases and Surgery Training and Research Hospital, Izmir,

Turkey

\section{INTRODUCTION}

Brucellosis is the most common zoonotic disease in the world caused by gramnegative, encapsulated, coccobacilli. It causes more than 500.000 new infections per year worldwide. Especially in developing countries continues to be a major health problem. While the annual incidence in Britain and the United States is 0.3 people/ 1 million, this ratio is increased to $1 / 1.000$ people in endemic areas such as Mediterranean basin and Arabian Peninsula. ${ }^{1-3}$

Human brucellosis may lead to many symptoms varying from mild flu-like findings to severe complications on the part of the musculoskeletal system, nervous system, and the heart. Weakness, fatigue, joint pain, weight loss, and 
sweating are the most seen non-specific complaints. $^{4}$

In this presentation, we aimed to draw attention to a case of brucellar spondylitis and spondylodiscitis in a patient who does not have any complaints about the involvement of musculoskeletal system and whose diagnosis was made with magnetic resonance imaging incidentally.

\section{CASE REPORT}

A 39-year old male was admitted to our hospital with a complaint of fever and cough. He was worked as a farmer. His fever was started 20 days prior to the admission. He stated that he went to another hospital with this complaint and he used cefuroxime axetil for ten days. However, he said that his complaints were not improved with this therapy and purulent cough has been started three days prior to admission to our out-patient clinic. His temperature at admission was $38.5^{\circ} \mathrm{C}$, and the pulse rate was 95 beats/minute. Other vital signs were normal. Physical examination was normal except inspiratory rales at the right lung base. There was no rash, no palpable lymph node.

His hemoglobin level at admission was $13.6 \mathrm{mg} / \mathrm{dl}$, leukocyte count was 2600/mm3 with $48 \%$ granulocytes, and platelet count was 103000/mm3. Erythrocyte sedimentation rate was 16 $\mathrm{mm} / \mathrm{h}$ and $\mathrm{C}$ reactive protein level was 30 $\mathrm{mg} / \mathrm{L}$ (normal range 0-5 $\mathrm{mg} / \mathrm{dL}$ ). Renal function was within normal limits but liver function was mildly elevated (alanine transferase, $140 \mathrm{U} / \mathrm{L}$; aspartat transferase, $96 \mathrm{U} / \mathrm{L})$. Other biochemical assays were in normal range. Computed tomography of the lungs showed ground-glass opacity in the superior segment of the right lower lobe and multiple subplevral nodules.

The patient was diagnosed with pneumonia and moxifloxacin $400 \mathrm{mg} /$ day was started. On the fifth day of treatment, the fever still remained elevated, and laboratory findings (leukopenia, high CRP levels and liver function tests) did not improve. Blood cultures taken at the beginning of treatment were negative. Computed tomography of the abdomen and vertebral magnetic resonance imaging were performed according to the protocol of fever of unknown origin.

When we questioned the patient's history again, we learned that he raised cows and sheep. He also accompanied her and his neighbors' animal births within two months. In serological assays the Rose Bengal and Wright test (Standart tube agglutination) were found positive at 1/160 titer.

Hepatomegaly (180 $\mathrm{mm}) \quad$ and splenomegaly $(152 \mathrm{~mm})$ were detected in abdominal computed tomography. Lomber magnetic resonance images demonstrated 
contrast uptake and signal changes compatible with medullar bone marrow edema at L5 vertebral corpus, at the sacral face and the superior and inferior part of the iliac face of the left sacroiliac joint and at the central part of the iliac face of right sacroiliac joint.

Oral 2x100 mg doxycycline and streptomycin $1 \mathrm{x} 1 \mathrm{~g}$ intramuscularly started with the diagnosis of brucellar spondylitis and spondylodiscitis. At the sixth day of treatment, fever completely reduced and the laboratory parameters were improved.

Written informed consent was obtained from the patient.

\section{DISCUSSION}

Joint pain has been seen in approximately $80 \%$ of Brucellosis cases. ${ }^{4}$ Of the brucellosis patients with osteoarticular involvement, vertebral osteomyelitis has detected in $10.4 \%$ and inflammatory spinal pain has observed in approximately $95 \%$ of these cases. ${ }^{5}$ In our patient, non-specific symptoms such as sweating, fever, fatigue, anorexia was observed, but there were no complaints about osteoarticular involvement such as, muscle and joint pain. In addition, there was not any backache that raises doubt about the vertebral involvement. Moxifloxacin therapy was initiated because clinical and laboratory findings were primarily consistent with pneumonia. However, defervescence was not observed with this therapy and the patient was diagnosed as brucellosis with osteoarticular involvement with the imaging methods that done according to unknown origin fever protocol. Generally, six-week treatment is sufficient in uncomplicated brucellosis. However extension of the duration of treatment for at least 90 days is recommended in the complicated brucellosis. In this case, if we did not perform radiographic examinations because of the absence of any osteoarticular symptoms, we would stop the therapy at the end of standard 42 days treatment, and the patient was probably come with recurrence. Therefore, lumbosacral imaging indications of brucellosis should be extended and sacroiliitis on imaging studies should be investigated more carefully.

Sacroiliitis is the most frequent osteoarticular complication of brucellosis. The lumbar spine is most frequently involved in brucellar spondylitis, followed by the thoracic and cervical spine. ${ }^{6}$ Lumbar spine involvement with bilateral sacroiliitis was observed in our patient.

Brucella species are usually transmitted by the ingestion of unpasteurized milk or milk products or by direct contact with infected animals. Therefore, animal carers, veterinarians, farmers, health workers, 
laboratory staff and slaughterhouse workers are at high risk. ${ }^{7}$ Our patient is a breeder and he was attended the birth of his and neighbors' cows and sheep within two month. So, professions, hobbies and animal theme should be questioned carefully, especially in patients whose fever did not reduce appreciably.

As a result, osteoarticular brucellosis should be considered in the differential diagnosis in patients who have nonspecific complaints such as fever, sweating, and fatigue even if the symptoms of osteoarticular involvement was not observed. Osteoarticular complications should be investigated with magnetic resonance imaging in patients diagnosed as brucellosis who have appropriate clinical findings.

\section{REFERENCES}

1. Skalsky K, Yahav D, Bishara J, Pitlik S, Leibovici L, Paul M. Treatment of human brucellosis: systematic review and meta-analysis of randomised controlled trials. BMJ. 2008;336(7646):701-4.

2. Solís García del Pozo J, Solera J. Systematic review and meta-analysis of randomized clinical trials in the treatment of human brucellosis. PLoS One. 2012;7(2):e32090.
3. Al-Nassir W. Brucellosis. (Cited 15 November 2013) http://emedicine.medscape.com/article 1213430-overview\#a0156. Accessed January 3, 2019.

4. Kursun E, Turunc T, Demiroglu Y, Arslan H. Evaluation of four hundred and forty seven brucellosis cases. Intern Med. 2013;52(7):745-50.

5. Colmenero JD, Ruiz-Mesa JD, Plata A, et al. Clinical findings, therapeutic approach, and outcome of brucellar vertebral osteomyelitis. Clin Infect Dis. 2008;46(3):426-33.

6. Turgut $M$, Sendur OF, Gürel $M$. Brucellar spondylodiscitis in the lumbar region. Neurol Med Chir (Tokyo). 2003;43(4):210-2.

7. Al Eissa YA. Brucellosis in Saudi Arabia: Past, Present and Future. Annals of Saudi Medicine. 1999;19(5):403-405. 